\title{
Light and Color in the Open Air: Introduction by the Feature Editors
}

James A. Lock

Cleveland State University, j.lock@csuohio.edu

Follow this and additional works at: https://engagedscholarship.csuohio.edu/sciphysics_facpub

Part of the Physics Commons

How does access to this work benefit you? Let us know!

\section{Publisher's Statement}

This paper was published in Applied Optics and is made available as an electronic reprint with the permission of OSA. The paper can be found at the following URL on the OSA website: http://www.opticsinfobase.org/ao/abstract.cfm?URI=ao-33-21-4535. Systematic or multiple reproduction or distribution to multiple locations via electronic or other means is prohibited and is subject to penalties under law.

\section{Original Citation}

Lock, James A. and Craig F. Bohren. "Light and Color in the Open Air: Introduction by the Feature Editors." Applied Optics 33 (1994): 4535-4536.

\section{Repository Citation}

Lock, James A., "Light and Color in the Open Air: Introduction by the Feature Editors" (1994). Physics Faculty Publications. 54.

https://engagedscholarship.csuohio.edu/sciphysics_facpub/54

This Article is brought to you for free and open access by the Physics Department at EngagedScholarship@CSU. It has been accepted for inclusion in Physics Faculty Publications by an authorized administrator of EngagedScholarship@CSU. For more information, please contact library.es@csuohio.edu. 


\title{
Light and color in the open air-introduction by the feature editors
}

\author{
James A. Lock and Craig F. Bohren
}

\begin{abstract}
The natural environment is still rich in new observable phenomena despite centuries of scientific observation. Reflecting this fact, the papers in this feature issue of Applied Optics report the observation and analysis of both new and well-known naked-eye optical phenomena.
\end{abstract}

There once was a time when people who were curious about nature, who carefully observed it, and who attempted to understand it were not called scientists. They were called natural philosophers. In our fastpaced modern society and with the reliance on technology in almost every aspect of our daily lives, we easily equate science with the study and the manipulation of the artificial environment that we have created. We easily lose sight of our interaction with the natural environment, leaving the discussion of this interaction to poets and artists, instead of to scientists as well.

The publication of Applied Optics is a thricemonthly celebration of technological optics and optical engineering. This issue, on the other hand, is a celebration of the observation and the analysis of naked-eye optical phenomena seen in the natural world around us by all who take the time to look. In the following pages our celebration takes three forms. First, we use modern analytical and computational methods and new experimental techniques to analyze well-known naked-eye optical phenomena in order to obtain a deeper understanding of them. Second, we report the observation of several exceedingly rare or previously unknown phenomena. The richness of the natural environment is reflected by the fact that, after so many centuries of scientific observation, there are still new phenomena to be seen by the patient and the lucky. Last, we appeal to

J. A. Lock is with the Department of Physics, Cleveland State University, Cleveland, Ohio 44115 . C. F. Bohren is with the Department of Meteorology, The Pennsylvania State University, University Park, Pennsylvania 16802-5013.

Received 22 February 1994; revised manuscript received 2 March 1994.

0003-6935/94/214535-02\$06.00/0.

(C) 1994 Optical Society of America. recent advances in physiology and psychology to understand the role that the idiosyncrasies of the human visual system play in observations.

The title of this collection of papers on naked-eye optical phenomena was chosen in honor of Marcel Minnaert's contribution to the field ${ }^{1}$ and the influence that this contribution has had on those who continue today to view and study these phenomena. In addition to his well-known book, ${ }^{2}$ which has been recently reprinted under the new title Light and Color in the Outdoors, ${ }^{3}$ he wrote a seminal paper on unusual optical phenomena in the natural environment. ${ }^{4}$ Various naked-eye optical phenomena cataloged in his book and paper have been analyzed in detail in four previous special issues of the Journal of the Optical Society of America and Applied Optics. ${ }^{5}$ We hope that this feature issue ${ }^{6}$ will be for each of us a source of increased appreciation of the natural environment and a reminder of the excitement, wonder, and joy that we experience when we observe it.

It sometimes happens that we interact with the natural environment in ways we neither anticipate nor intend. An example is provided by the odyssey of the paper "Subsuns, Bottlinger's rings, and elliptical halos" that appears in this feature issue. The original version of the paper avoided being consumed by the southern California brush fires of November 1993 by only $400 \mathrm{~m}$. A few months later, the revised version had to be dug out of the rubble produced by the January 1994 Los Angeles earthquake. We wish to thank the authors of this paper for their persistence in pursuing the publication of their work in the face of adversity. We also wish to thank the authors of all the other contributed papers whose dedication to the study of naked-eye optical phenomena made this feature issue a reality. We thank the Optical Society of America for judging this topic to be sufficiently important to warrant the forum and support for it that they have here provided. Finally, we 
thank Juliet Blackford, Ellen Kleiber, and Victoria Danahy of the OSA publications department for carefully watching over and keeping track of every detail involved in the production of this feature issue of Applied Optics.

\section{References}

1. W. C. Livingston, "Marcel Minnaert and optics in nature," Appl. Opt. 19, 648-649 (1980).

2. M. Minnaert, Light and Color in the Open Air (Dover, New York, 1954).

3. M. Minnaert, Light and Color in the Outdoors (Springer-Verlag, New York, 1993).

4. M. Minnaert, "Unusual or neglected optical phenomena in the landscape," J. Opt. Soc. Am. 58, 297-303 (1968).
5. Three previous collections of papers on atmospheric optics, which are associated with the Topical Meeting on Meteorological Optics, are J. Opt. Soc. Am. 69, 1051-1198 (1979); J. Opt. Soc. Am. 73, 1622-1664 (1983); and J. Opt. Soc. Am. A 4, 558-620 (1987). Another collection of papers on naked-eye optical phenomena in general, which is associated with the Topical Meeting on Light and Color in the Open Air, is Appl. Opt. 30, 3381-3552 (1991).

6. This collection grew out of presentations given at the Optical Society of America Topical Meeting on Light and Color in the Open Air, held at the Pennsylvania State University, University Park, Pa., 16-18 June 1993. This meeting was sponsored in part by the Office of Naval Research. A review of the meeting is given in M. E. Churma, "Halos, fuzzy suns, and swallowtails: light and color in the open air," Opt. Photon. News 4(12), 76, 87 (1993). 